\title{
The Development of a Project-Based Science Creative Learning (SCL) as a Learning Proponent of Students PAUD Dehasen Bengkulu University
}

\author{
Rika Partikasari $1 \mathrm{a}^{*}$ and Syisva Nurwita ${ }^{1, \mathrm{~b}}$ \\ ${ }^{1}$ Department of Early Childhood Education Teacher Education, Faculty of Teacher Training and Education, Dehasen University, Bengkulu, 38228, Indonesia \\ a rkpar85@gmail.com; bsyisvawita@gmail.com \\ ${ }^{*}$ Corresponding Author \\ Whatsapp number [ 085267261826]
}

How to Cite : Partikasari, R., Nurwita, S. (2019). The Development of a Project-Based Science Creative Learning (SCL) as a Learning Proponent of Students PAUD Dehasen Bengkulu University. International Journal for Educational and Vocational Studies, 1 (7), 739-743

\section{ARTICLE HISTORY}

Received:8 July 2019

Revised: 19 September 2019

Accepted: 10 October 2019

KEYWORDS

SCL Model

Project based

PAUD learning

\begin{abstract}
Early childhood Education Programs (PAUD) learning is currently starting to develop and diversify. Looking at the needs and curriculum nowadays we know that many PAUD schools have used K13 in their learning. The K13 PAUD learning strategy usually leads to a scientific approach. So, it needs to be designed in such a way as a learning strategy that implements supporting models in learning. The purpose of this reserach is to produce an effective development product in the form of a project-based Science Creative Learning (SCL) model as a learning proponent of PAUD students at Dehasen University Bengkulu. The research methode used in this research was Research and Development (R\&D) then proceed with the effectiveness test in the classroom by quasi experiment. The results of the research are obtained a textbook which is a product of the development model of the project-based Science Creative Learning (SCL) that can be used as a learning proponent for students of PAUD UNIVED BENGKULU. The textbook has been revised and validated by experts. The effectiveness of the use of textbooks in learning can be seen from the differences in learning outcomes of students of PAUD DEHASEN BENGKULU UNIVERSITY who use textbooks (experimental groups) with those who do not use textbooks (control groups). For the experimental group the lowest score was 67 and the highest was 100 . Whereas for the control group the lowest score was 58 and the highest was 83 .
\end{abstract}

This is an open access article under the CC-BY-SA license.

\section{INTRODUCTION}

Education is a long-term investment of Human Resources (HR) that has a strategic value for human sustainability in the world. Almost all countries assign education variable as something important and major in the context of national and state development. Likewise in Indonesia, It places education as a concerns and primary. It is strengthened by Preamble of 1945 Constitution paragraph IV which states that one of the National Goals of Indonesia is to educate the nation's life. Teaching and learning process is basically an activity implementing educational institution curriculum so that it can lead students to achieve the stated educational goals.

One way to achieve the goals of Indonesian education as expected is the need to improve the quality of education. The Improving of the education quality can be implemented in various ways, one of them is by increasing the role of the education quality itself, namely increasing the teaching staff, curriculum, educational facilities (facilities and infra- structure), media and learning models/approaches (teacher strategies in learning). Early Childhood Education (PAUD) is essentially education that is held with the aim of facilitating children's growth and development as a whole or emphasizing the development of all aspects of the child's personality. therefore, PAUD provides opportunities for children to develop their full potential and personality.

PAUD learning now begins to develop and vary. Looking at the needs and curriculum nowadays we know that many PAUD schools have used K13 in their learning process. The K13 PAUD learning strategy usually leads to a scientific approach. This approach is not interpreted as learning science but rather using a scientific process in learning. Based on observations as a lecturer during the learning process, especially in PAUD learning, there has not been much encouraging of students in learning to think and understand scientific concepts in. Thus, in the learning process, there will be a lack of scientific thinking process which will have a negative effect on children's behavior and 
achievement. The impact is even settled to the stage of higher education. So, it needs to be designed in such a way as a learning strategy that implements supporting models on PAUD K13 Learning process.

The utilization of used goods as a medium of creation and art has been encountered by us. With the skills and willingness, used goods can be managed into more valuable and even become aesthetic material, and also media in helping the learning process. In addition, the utilization of used goods indirectly can help and show the concern for environmental problems. Because, utilizing used goods such as plastics, cans, bottles, newsprint which is considered negative value trash can turn into positive value goods

Based on the description above, the researcher felt the need to find a solution to the problem, the researcher wanted to conduct a research entitled "Development of a Model of Science Based Creative Learning (SCL) as a learning proponent for PAUD Student Learning in Dehasen University Bengkulu".

\section{METHODS}

\subsection{Type of Research}

The type of research is in the form of research development (R\&D) which aims to produce certain products, and assess the effectiveness of these products (Sugiyono, 2018). The research is carried out to develop learning product. It was conducted to develop and validate the products used in education and learning in the form of materials, media, learning tools and/or strategies, evaluation tools, and so on to overcome educational problems, increase effectiveness PBM in the classroom/laboratory, and not to test theory (Widada, 2011).

\subsection{Research subject}

The subjects of the research were PAUD students on Sememster 3 of Dehasen University Bengkulu, academic year 2017/2018. The subject of this research has been considered by researchers in accordance with the aims and objectives of the research.

\subsection{Research Setting}

This research was conducted at Dehasen University, Bengkulu City, located in Jalan Meranti Raya No.32 Bengkulu City, in the third semester of PAUD students in the academic year 2017/2018.

\subsection{Development of Models, Learning Devices and Instruments}

The development of a project-based SCL learning model is carried out by following the stages of research development (R\&D) as a result of the modification of the development model proposed by Sugiyono (2018: 298).

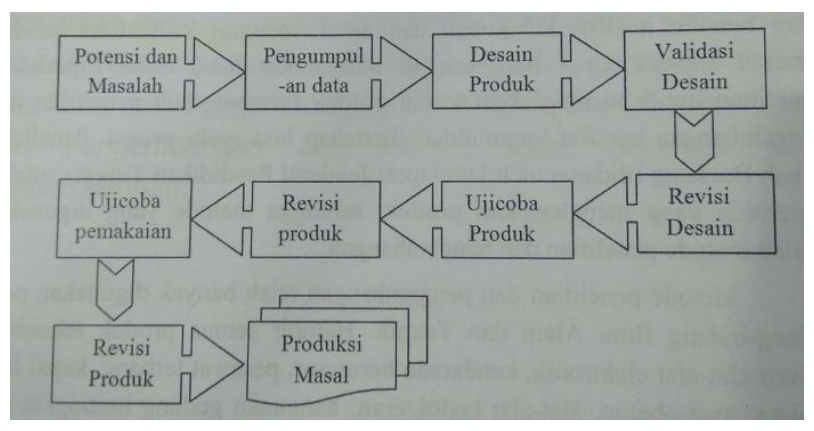

Figure1. Research Steps and Development

\subsection{Data collection technique}

According to (Sugiyono, 2011) Data collection techniques are the most strategic step in research, because the purpose of research is to get data.

\subsection{Data analysis technique}

In this research development the data analysis technique was carried out in accordace to the type of data collected, several things to consider in analyzing the data are:

1. Data analysis includes procedures, reduction, and presentation of data using tables, charts and graphs.

2. Data are classified based on the types and components of the product developed and related to the use of learning.

3. Data are analyzed descriptively and in the form of quantitative calculations.

4. Presentation of the results analysis is limited to factual things as a product revision.

5. The use of statistical analysis calculations in line with the problems raised and the products developed.

6. Reports must be formulated in the right format in such a way and be adjusted to the target or potential users of the product.

\subsection{Product Revision}

The Conclusions drawn from the analysis of trial data explain the products that are tested as a basis for decision making need to be revised or not, it is necessary with the proponent of justification that after revision, the products will be better, effective, efficient, attractive and easy for users and the revised components should be clearly stated and detailed. So, the decision to make a product revision needs to be accompanied by support/justification that after the product revised, It will be better, more effective, efficient, more attractive, and easier for users.

The effectiveness of the product testing is then carried out simply through data analysis of differences in learning outcomes of PAUD students in semester 3 Academic year 2017/2018 in those groups that do not use the product to those who use the project-based SCL learning book model during the learning process. 


\section{RESULTS AND DISCUSSION}

\subsection{Instrument Validation Results}

This research uses a learning achievement test instrument in the form of a multiple choice test. Before being used as a data collection tool, the instrument need be tested in order to get an instrument that meets the requirements as a measurement tool. Therefore, after the trial data has been collected, an analysis of validity and reliability is carried out. The trial of the instrument was conducted to 10 students of PAUD class on semester 3 of FKIP UNIVED Academic Year 2017-2018. The overall validity test results can be seen in the following table:

Table 1. Instrument Validity Test

\begin{tabular}{cc}
\hline \multicolumn{1}{c}{ Instrumen test } \\
\hline Question & $r_{\text {count }}$ \\
\hline 1 & 0,859 \\
\hline 2 & 0,905 \\
\hline 3 & 0,859 \\
\hline 4 & 0,740 \\
\hline 5 & 0,859 \\
\hline 6 & $-0,042$ \\
\hline 7 & 0,740 \\
\hline 8 & 0,859 \\
\hline 9 & 0,740 \\
\hline 10 & 0,739 \\
\hline 11 & 0,739 \\
\hline 12 & 0,905 \\
\hline 13 & $-0,147$ \\
\hline 14 & 0,905 \\
\hline 15 & 0,277 \\
\hline
\end{tabular}

The criteria for determining the instrument test items are declared valid and can be used as a measurement of learning outcomes if the value of $r$ count is higher than $r$ table with the provisions $\mathrm{df}=$ number of cases -2 or $10-2=8$ and a significance level of $5 \%$, i.e. the table $r=0.707$. The results of the validity test of the measuring instrument of the learning outcomes test showed that from the 15 items tested, it turned out that questions number 6,13 , and 15 were invalid ( $\mathrm{r}$ count $<\mathrm{r}$ table). So that the valid questions are 12 questions and then the 12 questions are used as a measurement tool.

The reliability test also needs to be done besides the validity test. If the instrument meets the validity and reliability test requirements, the instrument can be used to obtain data. The reliability test results can be seen in the following table:

Tabel 2. Instrument Realibility test

\begin{tabular}{cc}
\hline Instruments & Alpha \\
\hline Test & 0,923 \\
\hline
\end{tabular}

The criteria for determining the points of the test instrument are declared reliable and can be used as a measurement of learning outcomes if the correlation value is equal to or higher than 0.8 . The reliability test results show that the alpha value is $0.923 \geq 0.8$ which means the test (questions) are reliable. Furthermore, those 12 items can be used to obtain data.

Besides the questions, the textbook used is also validated formerly by experts. Validation was conducted by 2 experts consisting of 1 expert media who is a lecturer of PTIK Unived Bengkulu and 1 others is education expert (learning field) that is a lecturer of FKIP UNIVED BENGKULU. From the validation of textbooks conducted by experts some items corrected are; sentences in textbooks that are still not good and the use of symbols to be replaced with letters or numbers. From the results of the expert validation, later the researchers improve the textbook to make it better and can be used in learning activities in the PGPAUD Study Program.

\subsection{Description of Research Results Data (Difference in Learning Outcomes)}

\section{a. Data Description}

The following are presented the data descriptively from the experimental group and the control group:

Table 3. Pre test and Post Test result of Eksperimental dan Control Groups

\begin{tabular}{rrrcc}
\hline \multirow{2}{*}{ No } & \multicolumn{2}{c}{ Control } & \multicolumn{2}{c}{ Exsperiment } \\
\cline { 2 - 5 } & Pre Test & Post Test & Pre Test & Post Test \\
\hline 1 & 42 & 67 & 41 & 83 \\
\hline 2 & 65 & 67 & 58 & 82 \\
\hline 3 & 50 & 81 & 67 & 100 \\
\hline 4 & 58 & 75 & 50 & 93 \\
\hline 5 & 50 & 75 & 58 & 92 \\
\hline 6 & 67 & 83 & 42 & 75 \\
\hline 7 & 58 & 67 & 50 & 83 \\
\hline 8 & 50 & 67 & 42 & 67 \\
\hline 9 & 42 & 58 & 67 & 75 \\
\hline 10 & 42 & 67 & 67 & 100 \\
\hline Sum & 524 & 707 & 542 & 850 \\
\hline Avarage & 52,4 & 70,7 & 54,2 & 85,0 \\
\hline
\end{tabular}

From the pre-test and post-test results, It was obtained the average value of the pre-test for the experimental group was 54.2 and the average post-test of the experimental group was 85.0. For the control group the mean of pre-test was 52.4 and the average post-test result was 70.7 . From these results it is clearly seen that the post-test learning outcomes are higher than the pre-test scores. It means that the initial ability of students before learning will increase after learning is given.

From the post test results obtained, it can be seen that the student scores in the experimental class with the treatment of learning using textbooks resulting from the development of the SCL learning model based on the project is higher than the control class that does not use textbooks.

For the experimental group the lowest score was 67 and the highest score was 100 . Whereas for the control group the lowest score was 58 and the highest was 83 .

Considering that there are a lot of research data for the experimental group and the control group of 10 students each, the data is not normally distributed. If the amount of data is less than 30, then the data is not normally distributed or nonparametic (Susetyo, 2017).

The data above is then analyzed using 
non-parametric analysis, Mann Whitney. According to Susetyo (2017), nonparametric statistics are statistics which in the analysis technique do not require a normally distributed population or statistics that are free of distribution. thus, it is used if the researcher does not know the characteristics of the group that is the source of the sample, otherwise, nonparametric statistics are used if the sample is small so that the distribution of sampling from the statistics does not gain normal distribution. there are differences in the two data sets from independent samples. The Mann Whitney test is an alternative test from the $\mathrm{T}$ test. The Mann Withney test does not require the assumption that the data is normally distributed but only assumes that the populations has the same carracters. The advantage of this test compared to the $\mathrm{T}$ test is that it can be used in ordinary data or ranking data. This test can be called a $U$ test. The results of the analysis can be seen below:

The Mann Whitney test is used to determine whether

Tabel 4. Analisis Result of Mann Whitney Ranks

\begin{tabular}{llllrr}
\hline & Groups & & N & Mean Rank & Sum of Ranks \\
\hline Scores & Exsperiment & 10 & 13,95 & \\
\hline & Control & Total & 10 & 7,05 & 139,50 \\
\hline & & 20 & & \\
\hline
\end{tabular}

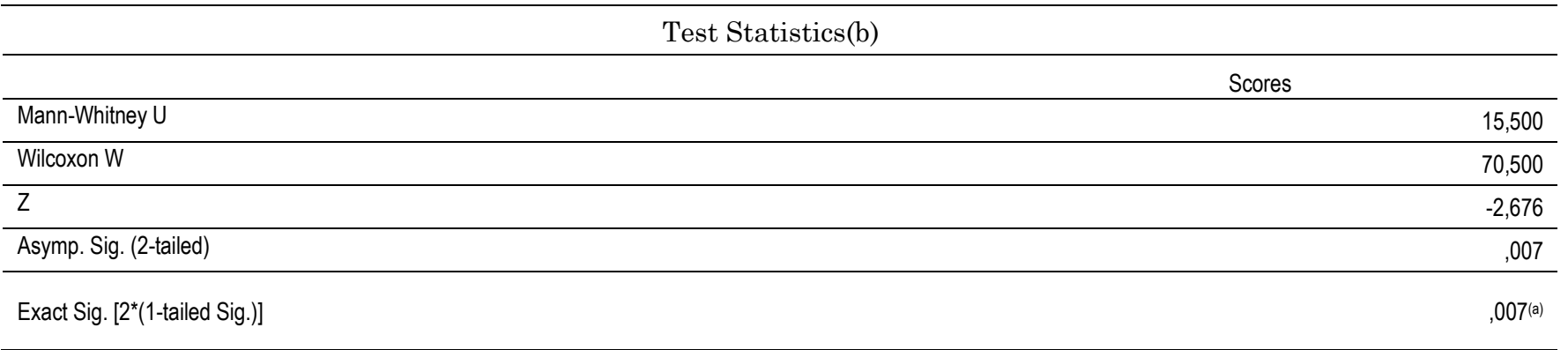

a Not corrected for ties.

b Grouping Variable:

\section{b. Hypothesis Testing}

The statistical hypotheses tested in this research are:

$\mathrm{H} 0=$ There is no difference in student learning outcomes taught using textbooks and those not using textbooks.

$\mathrm{Ha}=$ There are differences in student learning outcomes taught using textbooks and those not using textbooks.

From the Rank output, It can be seen that the mean score for the experimental group is higher than the mean score of the control group $(13.95>7.05)$. From the Mann-Whitney U test value, we can see in the "Test Statisticb" output the sig.2-tailed value (the significance for the two-tailed test) is 0.007 or the probability is above 0.05 (0.007 < 0.05). Therefore, Ho was rejected and $\mathrm{Ha}$ was accepted, which means that there was a difference between students group studying using textbooks and group who were not using books.

The difference in learning outcomes obtained between the control class and experiment shows that the use of textbooks in project-based SCL learning models is really effective to support improving learning outcomes. In line with the results of the research by I Made Teguh (2015) regarding the use of textbooks in learning, it gain that that the average validation results of students for textbooks were $84.07 \%$, which means good quality. This is also in accordance with the opinion of Chu and Reynolds (2017) that project based learning is an efficient method for building 21st century skills development, because it promotes critical thinking, problem solving, personal communication, information and media literacy, collaboration, teamwork and leadership. In addition, students who learn by applying project-based SCL learning usually work together to solve a given problem, develop a product for a particular audience, and assess both the project and the development process (Kokotsaki, Menzies, \& Wigins 2016; Tsybulsky, 2019).

\section{CONCLUSION}

A textbook is produced as a product of the development model of the project-based Science Creative Learning (SCL) model. It is a supporting book for student of PAUD UNIVED BENGKULU in learning process. The textbook has been revised and has been validated by experts.

The effectiveness of textbooks utilization in learning can be seen from the differences learning outcomes obtained by students of PAUD UNIVED, Bengkulu between the groups who use textbooks (experimental groups) with those who do not use textbooks (control groups). For the experimental group the lowest score was 67 and the highest score was 100 . Whereas for the control group the lowest score was 58 and the highest was 83 .

\section{REFERENCES}

Adinugraha, Fajar. (2018). Model Pembelajaran Berbasis Proyek Pada Mata Kuliah Media Pembelajaran. Jurnal SAP Vol. 3 No 1 Agustus 2018.

Chu, S. K. W., Reynolds, R. B., Tavares, N. J., Notari, M., \& Lee, C. W. Y. (2017). 21st century skills development through inquiry-based learning. 
Singapore: Springer. Available from: https://www.springer.com/gp/book/9789811024795

Direktorat Pembelajaran dan Kemahasiswaan Direktorat Jendral Pendidikan Tinggi. (2014). Panduan Penyusunan Capaian Pembelajaran Lulusan Prodi. Jakarta : Kemendikbud.

Hadi, Fikry, dkk. (2017). Pemanfaatan Barang Bekas Yang Bernilai Ekonomi Bagi Peningkatan Produktivitas Jiwa Entrepreneur Ibu Rumah Tangga RT.01/RW.12 Desa Limbungan Kecamatan Rumbai Pesisir. Jurnal Pengabdian Untukmu NegeRI Vol. 2, No.1 November 2017.

Halimah, Lelly. (2011). Silabus Belajar dan Pembelajaran. Jakarta : UPI

Kokotsaki, D., Menzies, V., \& Wiggins, A. (2016). Project-based learning: A review of the literature. Improving Schools, 19(3), $267 \mathrm{e} 277$.

Media Paud Jateng. Pembelajaran PAUD K13 Dengan Pendekatan Sainstifik. Jawa Tengah : PAUD Jateng.

Sugiyono. 2018. Metode Penelitian Kuantitatif, Kualitatif, dan R\&D. ALVABETA : Bandung.

Tegeh, I Made. (2015). Pengembangan Buku Ajar Mpdel Penelitian Pengembangan Dengan Model ADDIE. ALVABETA : Bandung.

Tim Pusat Kurikulum dan Pembukuan, Badan Penelitian dan Pengembangan Kementrian Pendidikan dan Kebudayaan. (2015). Buku Panduan Pendidik Kurikulum 2013 PAUD Anak Usia 5-6 Tahun. Jakarta : Kemendikbud.

Trianto, T. (2010). Mengembangkan Model Pembelajaran Tematik. PT. Prestasi Pustakaraya : Jakarta.

Tsybulsky\&Muchnik Rozanov, (2019). The Development of student-Teachers Professional Identity While Team-Teaching Science Classes Using Project Based Learning Approach : A Multi-Level Analysis. Teaching and Teacher Education. www. Elsevier.com/locate.tate. http://doi.org/10.1016/j.tate.2018.12.006.

Wibowo dan Suhandi. (2013). Penerapan Model Science Creative Learning (SCL) Fisika Berbasis Proyek untuk Meningkatkan Hasil Belajar Kognitif dan Keterampilan Berfikir Kreatif. Semarang: Jurnal Unnes.

Widada, Wahyu. (2010). Model Pembelajaran Berbasis Extended Level Triad++. Bengkulu: FKIP Unib.

Widada,Wahyu. 2011. Eksistensi Exended Level Trans pada Pelevelan Perkembangan Kognitif Mahasiswa Teori Graph. Bengkulu: Program Pascasarjana Pendidikan Matematika Fkip Unib.

Widada, Wahyu. (2012). Model Pendidikan Karakter Melalui Pembelajaran yang Membumi. Bengkulu: S2PMAT Fkip Unib. 